\title{
A tissue based chemical proteomics screen to identify novel G-kinase associated proteins (GKAPs)
}

\author{
Eleonora Corradini, Pepijn P Burgers, Michael Plank, Albert JR Heck, Arjen Scholten ${ }^{*}$
}

From 6th International Conference on cGMP: Generators, Effectors and Therapeutic Implications Erfurt, Germany. 28-30 June 2013

\section{Background}

Within the same cell, different signaling routes can signal through the same kinase. To still function in a specific manner, the kinase is localized in close proximity to its substrates and upstream signaling components. This is best described for cAMP-dependent protein kinase (PKA), which utilizes the diverse family of A-kinase anchoring proteins (AKAPs, $>50$ identified) for spatiotemporal control.

PKA's closest homologue is the cGMP-dependent protein kinase (PKG), however many details of its localized signaling are not well understood. Thus far, very little G-kinase anchoring proteins (GKAPs) have been identified, likely because they are lower in abundance than AKAPs. In addition, unlike as for AKAPs, common motifs in GKAPs that mediate the interaction have not been convincingly defined.

\section{Results}

Here we present a chemical proteomics approach which utilizes immobilized cAMP in combination with low concentrations of free cAMP or cGMP to specifically dissect the lower abundant PKG and its associated GKAPs, from the more prevalent PKA and interacting AKAPs. Combined with LC-MS/MS this proved a powerful screening tool for the discovery and characterization of novel protein kinase $\mathrm{G}$ anchoring proteins directly in several different tissues.

The isolated PKG fraction contained several known GKAPs (e.g. IRAG), but also a novel putative GKAP, Huntingtin associated protein 1 (HAP1). Further characterization of the PKG-HAP1 interaction was performed

\footnotetext{
* Correspondence: A.Scholten@uu.nl
Biomolecular Mass Spectrometry and Proteomics, Utrecht University, Utrecht,

* Correspondence: A.Scholten@uu.nl
Biomolecular Mass Spectrometry and Proteomics, Utrecht University, Utrecht, The Netherlands
}

Submit your next manuscript to BioMed Central and take full advantage of:

- Convenient online submission

- Thorough peer review

- No space constraints or color figure charges

- Immediate publication on acceptance

- Inclusion in PubMed, CAS, Scopus and Google Scholar

- Research which is freely available for redistribution

with classical biochemistry, cell biology and an interac作 tions of GFP-HAP1 and PKG-GFP. This powerful

\section{Conclusion}

Our data highlight the power of a tailored chemical proteomics approach to identify novel cGMP signaling hubs Cite this article as: Corradini et al: A tissue based chemical proteomics screen to identify novel G-kinase associated proteins (GKAPs). BMC Pharmacology and Toxicology 2013 14(Suppl 1):P16. 